\title{
Detection of Gene Expression Changes in Capsicum annuum L. Foliar Blight Caused by Phytophthora capsici Leon. Using qRT-PCR and Leaf Discs
}

\author{
Rhiana F. Jones and Paul W. Bosland \\ Department of Plant and Environmental Sciences, New Mexico State \\ University, Las Cruces, NM 88003
}

\author{
Robert L. Steiner \\ Department of Economics and International Business, New Mexico State \\ University, Las Cruces, NM 88003
}

\section{Richard W. Jones}

Genetic Improvement of Fruits and Vegetables Laboratory, U.S. Department of Agriculture-Agricultural Research Service, Beltsville Agricultural Research Center, 10300 Baltimore Avenue, Beltsville, MD 20705

\author{
Mary A. O'Connell ${ }^{1}$ \\ Department of Plant and Environmental Sciences, New Mexico State \\ University, Las Cruces, NM 88003 \\ Additional index words. chile peppers, disease resistance, disease syndrome, races
}

\begin{abstract}
Phytophthora capsici is responsible for multiple disease syndromes of Capsicum annuum but the resistance mechanism is still unknown. Evaluating gene expression during foliar blight can be used to identify expression patterns associated with resistance in Capsicum species. This study reports a direct comparison of gene expression changes during the foliar blight syndrome using two different races of $P$. capsici on $C$. annuum host plants with resistant and susceptible phenotypes to those races. Four genes were evaluated for differential expression following leaf inoculation with $P$. capsici. RNA isolated from leaves at three time points was used to quantify gene expression by quantitative real-time polymerase chain reaction (qRT-PCR). Of four genes tested, two had differential expression in response to $P$. capsici at 72 hours postinoculation,

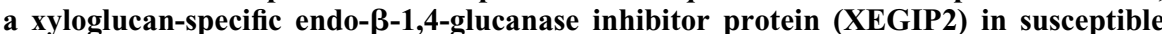
cultivar New Mexico Heritage 6-4 (NMH6-4), and a $C$. annuum cell wall protein (CWP) in resistant Criollo de Morelos 334 (CM334). Both genes had a 5-fold increase in transcription in leaves over the control. These results suggest that both genes are playing a role in disease resistance to foliar blight.
\end{abstract}

Chile pepper (C. annuum L.) is an important vegetable crop grown worldwide, a rich source of dietary $\beta$-carotene. The capsaicin in the fruit is used for pain relief and the extracted pigments for use in cosmetics and foods. In the United States alone, chile pepper consumption has increased to an annual per capita of 16.4 pounds while the U.S. crop is 4.8 million cwt with a value of $\$ 146.8$ million (Burden, 2014). One of the major challenges to chile pepper production is yield losses due to pathogen interactions,

\footnotetext{
Received for publication 27 Apr. 2015. Accepted for publication 21 July 2015 .

This work was supported in part by the New Mexico Agricultural Station, and support from the U.S. Department of Agriculture-Agricultural Research Service through a Specific Cooperative Agreement.

${ }^{1}$ Corresponding author. E-mail: moconnel@nmsu. edu.
}

specifically the soilborne oomycete $P$. capsici (Leonian, 1922).

No commercial variety of $C$. annuum has universal resistance to $P$. capsici (Walker and Bosland, 1999), but C. annuum landrace, CM334 has the highest level of resistance against all disease syndromes caused by $P$. capsici: i.e., root rot, foliar blight, fruit rot and, stem blight (Alcantara and Bosland, 1994; Walker and Bosland, 1999). To date, the genetic basis for resistance is not yet fully understood and the number of genes controlling resistance in CM334 remains unknown (Castro-Rocha et al., 2012; Rehrig et al., 2014). However, a multiple gene system for resistance has been proposed in the $P$. capsici-C. annuum pathosystem (Bnejdi et al., 2009; Lee et al., 2012; Monroy-Barbosa and Bosland, 2008; Walker and Bosland, 1999), and to further complicate the matter, variation in race or isolate of $P$. capsici, results in high genetic variability within the species (Truong et al.,
2010) and different cultivars of chile pepper are resistant to one race but may be susceptible to another (Monroy-Barbosa and Bosland, 2008; Sy et al., 2005). Inoculum concentration also appears to have an effect on gene expression in CM334 (Castro-Rocha et al., 2012; Lee et al., 2012). The relationship between $P$. capsici and its host plants is complex, and more research is needed to determine the molecular bases for the resistance to these disease syndromes (Lamour et al., 2012; Thines and Kamoun, 2010).

Regardless of the genetic mechanism of disease resistance, following exposure to a pathogen, most plants initiate gene expression changes (reviewed in Wise et al., 2007). Genes for proteins located in the plant cell wall and involved in plant defense mechanisms are often differentially expressed in response to many different types of pathogens (reviewed in Hückelhoven, 2007). Also, transcripts for a large complex of structurally diverse gene products called pathogenesis related (PR) are increased following exposure to pathogens (Soh et al., 2012). PR gene products are modeled to contribute to an overall defensive condition (Sels et al., 2008; Van Loon and Van Strien, 1999).

In previous work, we screened thousands of transcripts and identified 168 genes with differential expression patterns in C. annuum$P$. capsici root rot syndrome (Richins et al., 2010). Among those genes was a gene for a XEGIP; referred to here as XEGIP2 (Genbank accession: EB084827, 99\% similar to FJ606761). XEGIP2 has elevated expression in response to $P$. capsici (race PWB24) in root rot in both a resistant, CM334, and susceptible cultivar, NM6-4, of C. annuum (Richins et al., 2010). This gene is modeled to inhibit $P$. capsici produced xyloglucanspecific endo $\beta-1,4$ glucanase (XEG), which specifically attacks the xyloglucan bonds in plant cell walls (Yoshizawa et al., 2012) by hydrolyzing the xyloglucan and loosening the cross-linkages (Hayashi, 1989). XEGIPs inhibit XEGs from breaking down the xyloglucan in plant cell walls and provide some resistance against the pathogen (Jones, 2012; Scarafoni et al., 2010). XEGIPs have been identified in other members of the Solanaceae family such as potato (Solanum tuberosum L.), which has a complex XEGIP gene family with nine members in addition to the original XEGIP. Silencing of a member of this gene family resulted in increased susceptibility (Jones et al., 2006). In chile, a second XEGIP, referred to here as XEGIP1, is modeled to play a role in the hypersensitive response (HR) associated with disease resistance to bacterial pathogens (Choi et al., 2013).

This present study was designed to 1) determine if gene expression induced by pathogen challenge could be detected in leaf discs when the inoculum concentration was at levels used to assay for resistance phenotypes; 2) determine if the gene expression changes could distinguish resistant and susceptible hosts; and 3 ) determine if the gene expression changes could detect pathogen 


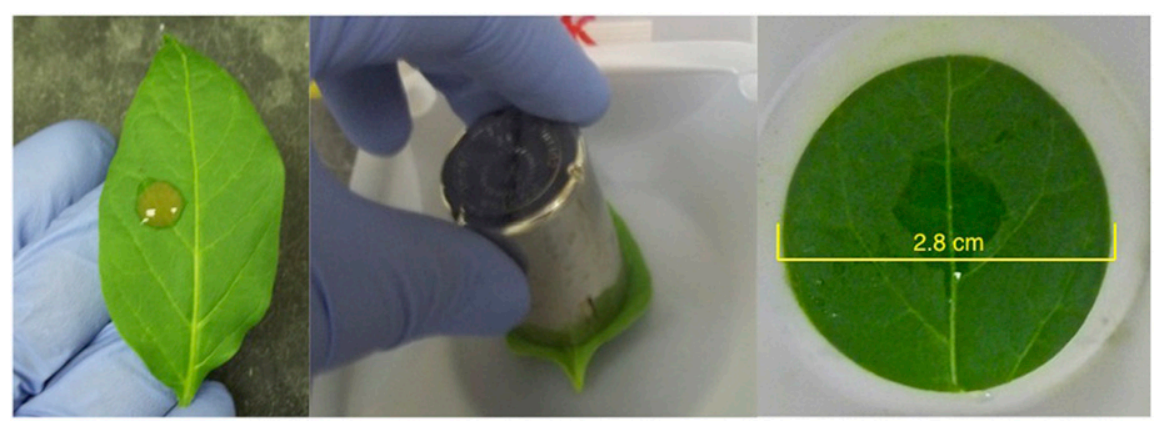

Fig. 1. Leaf tissue collection for RNA extraction. Leaf removed from plant, 2.8-cm diameter disc surrounding inoculation site was cut and weighed.

Table 1. Primer sequences used for qRT-PCR analysis.

\begin{tabular}{|c|c|c|c|}
\hline Gene & Primer sequences & $\begin{array}{l}\text { Annealing } \\
\text { temp }\left({ }^{\circ} \mathrm{C}\right)\end{array}$ & $\begin{array}{l}\text { Amplicon } \\
\text { size (bp) }\end{array}$ \\
\hline$\overline{\mathrm{CWP}^{\mathrm{z}}, \mathrm{DV} 643213^{\mathrm{y}}}$ & $\begin{array}{l}86 \mathrm{~F}^{\mathrm{x}}, \text { GTGAAACTCCCAACTCAGCGAAG } \\
\text { 241R, CACCATCAACTTCTACTTCCTGCTG }\end{array}$ & 64.0 & 179 \\
\hline $\begin{array}{l}\text { Universal stress } \\
\text { protein, EB084717 }\end{array}$ & $\begin{array}{l}\text { 65F, GTGATGGTGGCTATTGATG } \\
221 \mathrm{R}, \text { GCCATTAGTTGTGGAGATGC }\end{array}$ & 58.0 & 175 \\
\hline XEGIP1, JQ673414 & $\begin{array}{l}\text { 848F, CGAGAATCAGCACAGCGACACCTTTTAC } \\
\text { 1019R, CAACATCTATCACGGGAAGGTCTG }\end{array}$ & 64.0 & 194 \\
\hline XEGIP2, EB084827 & $\begin{array}{l}\text { 1270F, CGACAAACTACATGTGCC } \\
\text { 1453R, GGACGCACAAGTTACAAG }\end{array}$ & 55.5 & 183 \\
\hline
\end{tabular}

${ }^{{ }^{2}} \mathrm{CWP}=$ cell wall protein; XEG1P $=$ Xyloglucan-specific endo- $\beta$-1,4-glucanase inhibitor protein.

${ }^{\mathrm{y}}$ GenBank Accession numbers.

${ }^{x}$ The nucleotide positions of the start of the forward $(\mathrm{F})$ and reverse $(\mathrm{R})$ primers.

Table 2. Efficiency and reliability of qRT-PCR analysis. The efficiency and $R^{2}$ values for the qRT-PCR calibration curves generated for each gene in four replicate assays.

\begin{tabular}{lccc}
\hline Gene & Pathogen/trial & Efficiency & $R^{2}$ \\
\hline XEGIP1 & PWB24/1 & 0.91 & 0.999 \\
& PWB54/1 & 0.91 & 0.999 \\
& PWB24/2 & 0.90 & 0.998 \\
XEGIP2 $^{z}$ & PWB54/2 & 0.91 & 0.997 \\
& PWB24/1 & 0.98 \\
& PWB54/1 & 1.03 & 0.998 \\
CWP $^{z}$ & PWB24/2 & 0.94 & 0.994 \\
& PWB54/2 & 0.95 & 0.992 \\
& PWB24/1 & 0.90 & 0.998 \\
Universal stress protein & PWB54/1 & 0.93 & 0.990 \\
& PWB24/2 & 0.99 & 0.970 \\
& PWB54/2 & 0.90 & 0.952 \\
& PWB24/1 & 0.95 & 0.999 \\
& PWB54/1 & 0.97 & 0.998 \\
& PWB24/2 & 0.93 & 0.998 \\
CWPP & PWB54/2 & 0.90 & 0.997 \\
\hline
\end{tabular}

${ }^{{ }^{z} \mathrm{CWP}}=$ cell wall protein; $\mathrm{qRT}-\mathrm{PCR}=$ quantitative real-time polymerase chain reaction; XEG1P $=$ Xyloglucan-specific endo- $\beta$-1,4-glucanase inhibitor protein.

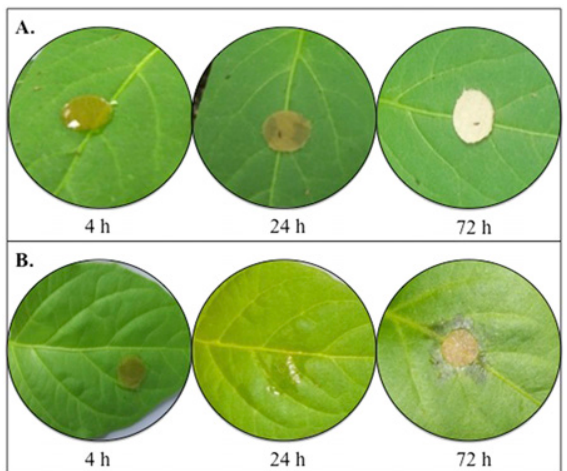

Fig. 2. Phytophthora capsici (race PWB24) inoculated leaves in Capsicum annuum at 4, 24, and 72 h. (A) resistant landrace Criollo de Morelos 334 (CM334); (B) susceptible cultivar NMH6-4. kingdoms, with potential roles in biotic and abiotic stresses in plants (Kerk et al., 2003); and two were separate gene family members of the XEGIP class, i.e., XEGIP1 and XEGIP2. The genes for the Universal Stress Protein and the CWP were selected for investigation in this foliar blight study since transcripts for these genes increase in response to root rot challenge only in resistant genotypes of Capsicum (Richins et al., 2010).

\section{Materials and Methods}

Chile and P. capsici inoculation. Seeds of C. annuum L., CM334 and NMH6-4, were germinated in Metro Mix 360 Professional Growing Medium (Agawam, MA), for about 2 weeks at $28 \pm 1{ }^{\circ} \mathrm{C}$ in a growth chamber. Seedlings (36 of each cultivar) were then transferred to $10.16 \times 10.16 \mathrm{~cm}$ plastic containers (T.O. Plastics, Minneapolis, MN) and planted in Metro Mix 360. Plants were maintained in a greenhouse until they reached the four to six true leaf stage. For foliar blight inoculation, two races of $P$. capsici were used, a virulent New Mexico isolate PWB24 (ATCC MYA 2289) race 1, mating type A1 (Sy et al., 2008), and a lesser virulent New Jersey isolate PWB54 (Hallock, ATCC MYA 2338) race 9, mating type A2 (Oelke et al., 2003). Phytophthora isolates were established on V8 agar (Tuite, 1967) following essentially the protocol of MonroyBarbosa and Bosland (2010). Squares of agar-containing $P$. capsici were cut from the V8 plates and transferred to a new plate with enough distilled water to cover the squares. Plates were placed under a fluorescent light for 2 days to induce sporangia formation. Plates were then placed in $\mathrm{a}-10^{\circ} \mathrm{C}$ freezer for $10 \mathrm{~min}$ of cold shock to release the zoospores, and then transferred to a $29{ }^{\circ} \mathrm{C}$ incubating oven for $30 \mathrm{~min}$ to allow recovery. A hemocytometer (Hausser Scientific BrightLine Hemacytometer, VWR, Radnor PA) was used to calculate the concentration of zoospores and stock solutions were adjusted with distilled water to achieve a final concentration of 40,000 zoospores $/ \mathrm{mL}$. Plants in their pots were placed in one of three $99-\mathrm{L}$ plastic bins: $81.6 \times 48.6 \times 34.9 \mathrm{~cm}$ (Sterilite, Townsend, MA); adding $500 \mathrm{~mL}$ of hot $\left(53{ }^{\circ} \mathrm{C}\right)$ water to the bins created a humid environment. A $0.5 \mathrm{~cm}$ disc of germination paper (Nasco, Modesto, CA) was placed on one leaf per plant and $50 \mu \mathrm{L}$ of inoculum per leaf was dispensed using a micropipette. Control plants received $50 \mu \mathrm{L}$ of distilled water on the disc.

Experimental and statistical design. A complete randomized split plot design was used and two complete replications of the experiments were carried out. Each replication, called "trial" contained two experiments, exposure of both cultivars to one race (\#1 PWB24), and then separately to the other race (\#2 PWB54). Then repeated for the second trial, exposure to one race (\#3 PWB24), and again separately to the other (\#4 PWB54) for a total of four experiments in 
Table 3. Factorial analysis of variance and least Squares (LS) means separation for xyloglucan-specific endo- $\beta$-1,4-glucanase inhibitor protein (XEGIP2) transcript accumulation.

\begin{tabular}{|c|c|c|c|c|c|c|c|}
\hline \multirow[b]{2}{*}{ Source } & \multirow{2}{*}{$\begin{array}{l}\text { Degrees of } \\
\text { freedom }\end{array}$} & \multicolumn{3}{|c|}{ Trial 1} & \multicolumn{3}{|c|}{ Trial 2} \\
\hline & & $4 \mathrm{~h}$ & $24 \mathrm{~h}$ & $72 \mathrm{~h}$ & $4 \mathrm{~h}$ & $24 \mathrm{~h}$ & $72 \mathrm{~h}$ \\
\hline Bin (Race) & 4 & 0.0265 & 0.3174 & 0.4601 & 0.5914 & 0.2372 & 0.5143 \\
\hline Treatment & 1 & 0.0880 & 0.0569 & 0.1059 & 0.2746 & 0.0584 & 0.1205 \\
\hline Cultivar*treatment & 1 & 0.1978 & 0.2444 & 0.1109 & 0.9916 & 0.8511 & 0.0778 \\
\hline Cultivar*race & 1 & 0.4594 & 0.4825 & 0.0708 & 0.1027 & 0.6584 & 0.1106 \\
\hline Treatment*race & 1 & 0.2972 & 0.8007 & 0.1961 & 0.3849 & 0.3918 & 0.0896 \\
\hline CM334* PWB54 treatment & & 0.4231 & 0.3636 & 0.8423 & 0.7313 & 0.4994 & 0.9754 \\
\hline NMH6-4* PWB24 treatment & & 0.7747 & NA & $* * 0.0456$ & 0.4324 & 0.0576 & $* * 0.0007$ \\
\hline NMH6-4* PWB54 treatment & & 0.0930 & NA & 0.6585 & 0.2543 & 0.6658 & 0.8596 \\
\hline \multicolumn{8}{|l|}{ Group 2} \\
\hline CM334* inoculated & & 0.2060 & 0.2753 & 0.6904 & 0.9987 & 0.1177 & 0.9987 \\
\hline CM334* mock-inoculated & & $* 0.0299$ & 0.3063 & 0.7685 & 0.1732 & 0.1691 & 0.9082 \\
\hline NMH6-4* inoculated & & $* 0.0428$ & NA & 0.0556 & 0.3050 & $* 0.0030$ & $* 0.0011$ \\
\hline \multicolumn{8}{|l|}{ Group 3} \\
\hline PWB54*inoculated & & $* 0.0240$ & 0.8879 & 0.9383 & 0.8796 & 0.9800 & 0.9532 \\
\hline PWB54*mock-inoculated & & 0.9531 & 0.5666 & 0.9837 & 0.4649 & 0.4285 & 0.7812 \\
\hline
\end{tabular}

The $P$ values are listed for comparisons of gene expression abundances at times post inoculation $(4,24$, and 72 h) by one of two Phytophthora capsici strains (PWB24, PWB 54) on either the resistant landrace Criollo de Morelos 334 (CM334) or the susceptible cultivar New Mexico Heritage 6-4 (NMH6-4). Two independent replications, trial 1 and trial 2 are reported; LS means separated by treatment, race, and cultivar. Significant differences $(P<0.05)$ are indicated by an asterisk and significant differences that corresponded across both trials are indicated by a double asterisk. Group 1, mock inoculated vs. inoculated for each cultivar by race combination; group 2, PWB24 vs. PWB54 for each cultivar by treatment combination; group 3, CM334 vs. NMH6-4 for each treatment by race combination.

Table 4. Factorial analysis of variance and least Squares (LS) means separation for cell wall protein transcript accumulation.

\begin{tabular}{|c|c|c|c|c|c|c|c|}
\hline \multirow[b]{2}{*}{ Source } & \multirow{2}{*}{$\begin{array}{l}\text { Degrees of } \\
\text { freedom }\end{array}$} & \multicolumn{3}{|c|}{ Trial 1} & \multicolumn{3}{|c|}{ Trial 2} \\
\hline & & $4 \mathrm{~h}$ & $24 \mathrm{~h}$ & $72 \mathrm{~h}$ & $4 \mathrm{~h}$ & $24 \mathrm{~h}$ & $72 \mathrm{~h}$ \\
\hline Bin (Race) & 4 & 0.5359 & 0.1508 & 0.1724 & 0.0237 & 0.2662 & 0.9489 \\
\hline Cultivar*treatment & 1 & 0.8300 & 0.9185 & 0.2740 & 0.7329 & 0.5964 & 0.8905 \\
\hline Cultivar*race & 1 & 0.4370 & 0.0915 & 0.0333 & $* 0.0140$ & 0.1046 & 0.8365 \\
\hline Treatment*race & 1 & 0.7044 & 0.0530 & 0.7643 & 0.9183 & 0.1135 & 0.1645 \\
\hline CM334* PWB54 treatment & & 0.2013 & 0.8882 & 0.1085 & 0.1730 & $* 0.0413$ & $* 0.0011$ \\
\hline NMH6-4* PWB24 treatment & & 0.4784 & $* 0.0457$ & 0.2010 & 0.7455 & 0.8776 & 0.6831 \\
\hline NMH6-4* PWB54 treatment & & 0.8079 & 0.1530 & 0.1979 & 0.7655 & 0.2460 & 0.1987 \\
\hline \multicolumn{8}{|l|}{ Group 2} \\
\hline CM334* inoculated & & 0.2131 & 0.0549 & 0.3412 & 0.1495 & 0.0951 & $* 0.0009$ \\
\hline CM334* mock-inoculated & & 0.8625 & 0.9475 & 0.7516 & $* 0.0234$ & 0.6294 & 0.1186 \\
\hline NMH6-4* inoculated & & 0.9000 & 0.4979 & 0.1928 & $* 0.0218$ & 0.0764 & 0.2190 \\
\hline PWB54*inoculated & & 0.3948 & 0.5638 & 0.3316 & $* 0.0499$ & 0.3215 & 0.4482 \\
\hline PWB54*mock-inoculated & & 0.4180 & 0.3550 & 0.8240 & 0.0865 & 0.1098 & 0.5957 \\
\hline
\end{tabular}

The $P$ values are listed for comparisons of gene expression abundances at times post inoculation $(4,24$, and $72 \mathrm{~h})$ by one of two Phytophthora capsici strains (PWB24, PWB 54) on either the resistant landrace Criollo de Morelos 334 (CM 334) or the susceptible cultivar New Mexico Heritage 6-4 (NMH6-4). Two independent replications, trial 1 and trial 2 are reported; LS means separated by treatment, race, and cultivar. Significant differences $(P<0.05)$ are indicated by an asterisk and significant differences that corresponded across both trials are indicated by a double asterisk. Group 1, mock inoculated vs. inoculated for each cultivar by race combination; group 2, PWB24 vs. PWB54 for each cultivar by treatment combination; group 3, CM334 vs. NMH6-4 for each treatment by race combination.

two trials. The three bins each contained biological replication of the same treatments, treatment and location were randomized to plant and bin, respectively. Each experiment consisted of 54 plants.

Two statistical analyses (SAS 9.4; SAS Institute Inc., Cary, NC) were conducted, first a factorial analysis of variance (ANOVA) with all factors included in the model, both treatments, both races, and both cultivars (overall $\mathrm{F}$ test was significant at $P<0.05$ ). Second, least Squares (LS) means pairwise comparisons were conducted to evaluate specific relationships. No statistical analysis was conducted comparing differences in transcript abundance between trials 1 and 2 over time, but if there were similar trends in both trials, these results were discussed.
RNA extraction, cDNA synthesis, and $q R T-P C R$ analysis. Leaf tissue was harvested from both control and inoculated plants at 4 , 24 , and $72 \mathrm{~h}$ postinoculation. Uniform discs surrounding the inoculation site were cut using a Morton stainless steel culture tube cap (2.8 cm diameter) (Fisher Scientific, Waltham, MA) (Fig. 1). The leaf disc was immediately placed into liquid nitrogen and 


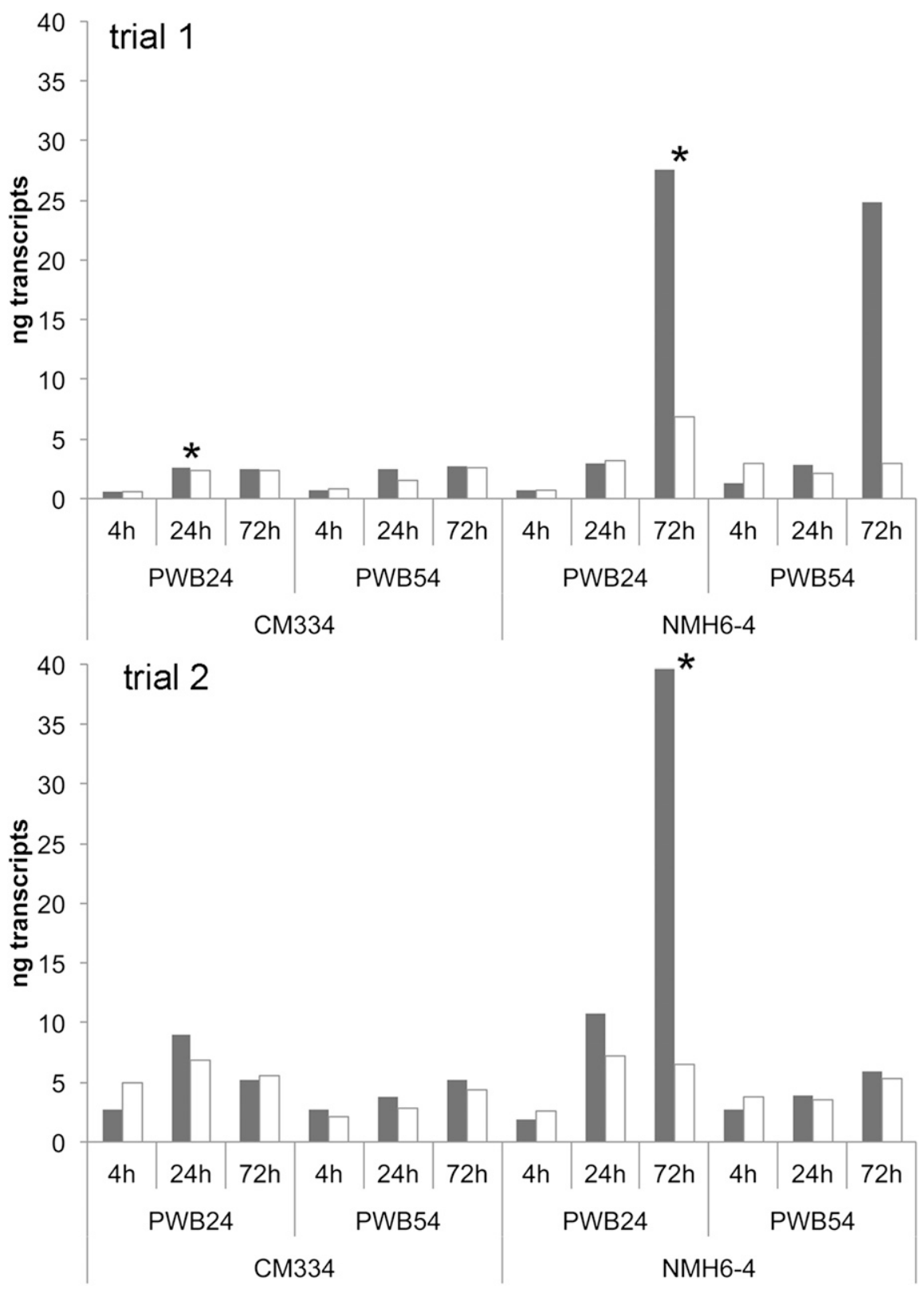

Fig. 3. Xyloglucan-specific endo- $\beta$-1,4-glucanase inhibitor protein (XEGIP2) transcript abundance (ng/10 mg total RNA) during foliar blight. Replicate trial results (trial 1, upper panel; trial 2, lower panel) for inoculated (gray bars) and mock-inoculated (open bars) CM334 or NuMex Heritage 6-4 (NMH6-4) plants challenged with Phytophthora capsici strains, PWB24 or PWB 54. * indicates significant difference based on treatment, for a specific time, cultivar, and pathogen combination.

stored at $-80{ }^{\circ} \mathrm{C}$ until RNA isolation and cDNA synthesis was conducted as described earlier (Rodriguez-Uribe et al., 2012). RNA isolated from the leaf discs and for use in qRT-PCR was assessed to be intact, as the ribosomal $28 \mathrm{~S}$ and $18 \mathrm{~S}$ rRNA bands were readily detected (data not shown). Total RNA yields from these samples ranged between 1 and $50 \mu \mathrm{g}$.

Primer sequences in the qRT-PCR analysis were designed for each of the gene transcripts under investigation (Table 1). Standard curves for each gene were generated for absolute quantification of samples using qRT-PCR; The KAPA $^{\mathrm{TM}}$ SYBER $^{\circledR}$ FAST One-Step qRT-PCR (Kapa Biosystems, Wilmington, MA) kit and protocol or equal to $90 \%$ with $R^{2}$ values greater than 0.95 . This method, an absolute quantification of transcript abundance in contrast to a relative quantification approach, does not rely on the presumption that reference or "housekeeping" genes are expressed at constant levels in all tissues examined. This premise can be very difficult to prove (Ghareeb, et al., 2011; Lu et al., 2012; Sellars et al., 2007). We regularly report absolute transcript abundances from qRT-PCR data (Keyhaninejad et al., 2014; Kilcrease et al., 2015; RodriguezUribe et al., 2012), and find this method able to provide precise and reproducible transcript abundances.

\section{Results and Discussion}

Disease responses. The appearance of the leaf tissue surrounding the inoculation site was observed during the time course of these experiments. Representative images of leaves from the resistant line CM334 and the susceptible cultivar NMH6-4 are shown in Fig. 2. There were no visible symptoms at any time point with either race of $P$. capsici on the leaves of CM334. For NMH6-4, there were no visible symptoms at $4 \mathrm{~h}$ postinoculation, visible necrosis under leaf disc was observed beginning at $24 \mathrm{~h}$, spreading of necrosis and eventual defoliation occurred by $72 \mathrm{~h}$. This also was observed with either race of $P$. capsici. For each experiment, additional plants of each genotype were inoculated and then maintained for 1 week in all of the experiments, to ensure that the experimental conditions would cause disease in the susceptible plants. In all cases, the inoculum level of 40,000 zoospores $/ \mathrm{mL}$ caused phenotypic changes in the susceptible plant, resulting in death of the NMH6-4 plant by the end of the week, and no changes in the resistant plant, CM334, by the end of the week.

Gene expression changes in response to $P$. capsici challenge. Factorial ANOVA and LS means analysis was carried out using SAS 4.1 statistical software to determine significant differences in transcript abundances of each of the four genes: CWP, universal stress protein, XEGIP1, and XEGIP2. These analyses compared transcript levels for each gene between inoculated and mock-inoculated leaves at each time point: $4 \mathrm{~h}, 24 \mathrm{~h}$, and $72 \mathrm{~h}$; and for each race and host genotype combination. No significant differences due to treatment were detected in transcript levels for either XEGIP1 or for the universal stress protein for any time point, for either race or either C. annuum host. Previous studies found upregulation of pepper XEGIP1 in a disease challenge, however these studies involved interactions with a bacterial pathogen (Choi et al., 2013). This suggests that pepper XEGIP1 responds differently to the presence of oomycete and bacterial pathogens. Significant differences due to treatment were detected in XEGIP2 and the CWP. ANOVA tables reporting the $P$ values for the factorial analysis and for the LS means of the gene expression comparisons for XEGIP2 and the 


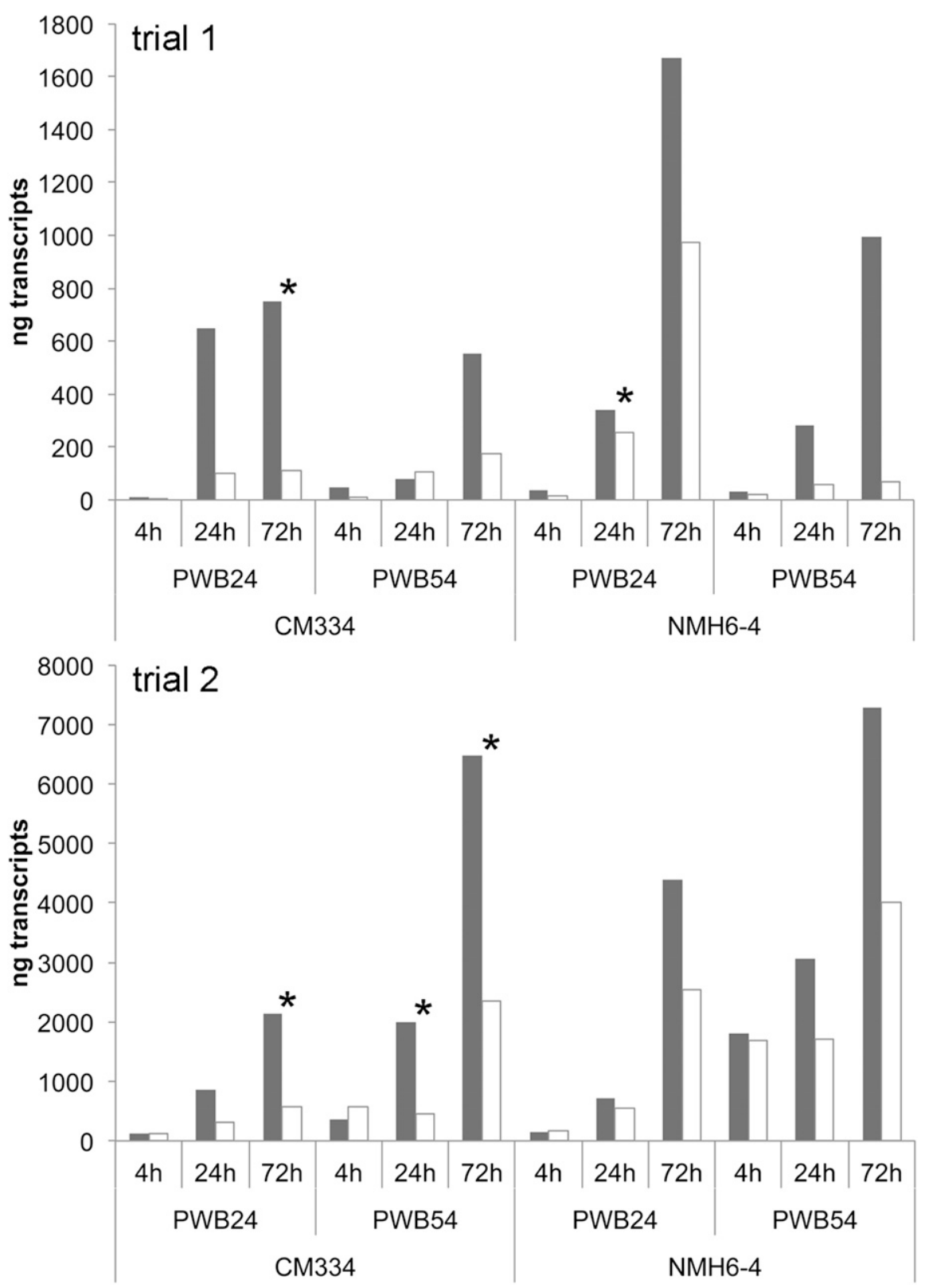

Fig. 4. Cell wall protein (CWP) transcript abundance (ng/10 mg total RNA) during foliar blight. Replicate trial results (trial 1, upper panel; trial 2, lower panel) for inoculated (gray bars) and mock-inoculated (open bars) CM334 or NuMex Heritage 6-4 (NMH6-4) plants challenged with Phytophthora capsici strains PWB24 or PWB 54. * indicates significant difference based on treatment, for a specific time, cultivar and pathogen combination.

CWP are presented in Tables 3 and 4, respectively.

$X E G I P 2$. There were no significant differences between treatments in the factorial ANOVA in trial 1 or 2 . When further analyzed using LS means to look at specific relationships, there were significant differences in transcript abundance between treatments in XEGIP2 across both trials in PWB24 inoculated NMH6- 4 chiles at $72 \mathrm{~h}, P$ value $=0.0456$ in trial 1 , and $P$ value $=0.0007$, in trial 2 (Table 3). Treatment of the leaves, inoculated vs. mock-inoculated, over time for each cultivar by race comparison is given in Fig. 3, upper panel is trial 1 (A) and lower panel is trial 2 (B). Significant differences in both trials were detected for this gene. provide resistance to the plant. In roots inoculated with PWB24 (150 mL at 200,000 zoospores/mL), the XEGIP2 gene had elevated transcript abundance in roots of both the resistant CM334 and susceptible NM6-4 (Richins et al., 2010). As reported here, in foliar blight, the XEGIP2 had differential expression only in the susceptible NMH6-4 cultivar. Root rot and foliar blight are genetically distinct disease syndromes and resistance is managed by a different assembly of genes for each disease syndrome (Oelke et al., 2003; Walker and Bosland, 1999). Together, these results suggest that XEGIP2 could be involved in a syndrome-specific downstream defense response.

Cell wall protein. There was overall significance of the $\mathrm{F}$ test in the factorial ANOVA with significant differences in transcript abundance between treatment at both $24 \mathrm{~h}(P$ value $=0.0064)$ and $72 \mathrm{~h}(P$ value $=$ $0.0017)$ in trial 1 and in trial 2 also at $24 \mathrm{~h}$ and $72 \mathrm{~h}$ (both $P$ values $=0.0185)$ (Table 4$)$. Figure 4 shows the leaves for the inoculated vs. mock-inoculated over time for each cultivar by race comparison, the upper panel is trial 1 (A) and lower panel is trial 2 (B). In both trials, a significant difference in CWP transcript accumulation was demonstrated in PWB24 inoculated leaves of CM334 chiles at $72 \mathrm{~h}, P$ value $=0.0254$ in trial 1 , and $P$ value $=$ 0.017 in trial 2 . The transcript abundance levels are much higher in the second trial, but trends between the two trials are consistent.

The annotation for this gene is based on $99 \%$ sequence similarity to a previously annotated $C$. annuum CWP (Genbank accession: AF242730). Transcripts for this CWP are induced during the HR in response to TMV, with higher transcript abundance occurring in response to an avirulent TMV and lower transcript abundance in response to the virulent TMV (Shin et al., 2001), indicating that this gene may have differential expression with response to pathotype. The F test was significant for CWP transcript abundance between treatments at 24 and $72 \mathrm{~h}$ when all factors were included in the model (Table 4), showing that chile leaves inoculated with $P$. capsici, increased transcription of the CWP. When specific interactions between race and cultivar are examined, there was an overall significant difference in transcript abundance between treatments in leaves of the resistant cultivar CM334 at $72 \mathrm{~h}$ only. There was a 5 -fold increase in CWP transcript in CM334 chiles inoculated with PWB24 in comparison with mockinoculated, 33.58 vs. $6.67 \mathrm{ng} / 10 \mathrm{mg}$ total RNA, respectively (Fig. 4).

Detection of significant differences in transcription of the CWP gene due to pathogen treatment was difficult as there was an overall increase in transcription of this gene due to time in the experimental chamber (Fig. 4), so potential differences attributable to inoculation were likely overwhelmed by differences due to time in the humid chamber, or to any associated gene expression changes due to leaf development. Further, the variability of this measure increased steadily 
with time as well. For example in trial 1, the mean square error for the abundance of CWP transcripts was $7.1 \times 10^{-5}$ at $4 \mathrm{~h}, 4.89 \times 10^{-3}$ at $24 \mathrm{~h}$, and 1.45 at $72 \mathrm{~h}$. As time increased, the biological variability within the leaf discs would also increase; necrotic sectors and healthy tissue were clearly visible at this time point (Fig. 2).

Since the CWP gene had greater transcript abundance in the resistant chile, CM334, the CWP may be involved in resistance to PWB24 in this pathosystem. This increase in CWP transcription was not detected until $72 \mathrm{~h}$ postinoculation though, again suggesting that this gene is likely to play a role downstream in a signal cascade of defense responses. The expression pattern of the CWP in response to foliar blight matched with what was seen in the Richins et al. (2010) root rot study. Since transcription of the CWP is induced only in the resistant line of $C$. annuum in response to $P$. capsici challenge in the root rot and foliar blight, it therefore could be a potential marker for distinguishing susceptible and resistant lines (Richins et al., 2010).

Detection of differential transcription at a low pathogen inoculation concentration. A goal of this study was to determine if differential gene expression could be detected at a lower concentration of $P$. capsici inoculum. In a root rot study designed to detect gene expression changes, roots were inoculated with $150 \mathrm{~mL}$ at 200,000 zoospores $/ \mathrm{mL}$ (Richins et al., 2010) whereas in another study designed to characterize resistance phenotypes, roots were inoculated with $5 \mathrm{~mL}$ at 20,000 zoospores $/ \mathrm{mL}$ and leaves with $45 \mu \mathrm{L}$ at 40,000 zoospores $/ \mathrm{mL}$ (Sy et al., 2005). In this study, we tested for gene expression changes using inoculum rates similar to those used in resistance phenotype screens, $50 \mu \mathrm{L}$ at 40,000 zoospores $/ \mathrm{mL}$. We were able to identify reproducible changes in gene expression in two of the four genes we tested using this lower inoculum and leaf disc assay system.

A source of confusion in replicating experiments on the resistance mechanism in the $C$. annuum and $P$. capsici pathosystem could be due in part to the variety of methods used to test for resistance. Variance in inoculation concentrations and methods, source of susceptible parents, and environmental conditions are all factors that could alter results (Lee et al., 2012). The $P$. capsici-resistant cultivar, CM334, has a consistent mean disease index (level of infection) across three increasing concentrations of $P$. capsici inoculum $(10,000$ zoospores $/ \mathrm{mL}, 100,000$ zoospores $/ \mathrm{mL}$, and $1,000,000$ zoospores/mL), while all susceptible cultivars exhibit an increase in mean disease index as inoculum concentration increases (Lee et al., 2012). In $\mathrm{F}_{2}$ populations segregating for the CM334 resistance trait, the resistance phenotype varies with inoculum densities as well as with parental genotypes. Therefore it appears that resistance not only depends on the susceptible parent genotype (Sy et al., 2005; Walker and Bosland, 1999), but also on inoculum concentrations. On the basis of segregation ratios (9:7) in the $C$. annuum and $P$. capsici pathosystem, resistance requires complementary genes working in conjunction with $\mathrm{R}$ genes to confer resistance at high inoculum concentrations (Lee et al., 2012). A logical extension of this phenotypic analysis is that varying concentrations of pathogen inoculum would cause varying levels of gene expression of PR genes. In this study, the concentration of inoculum used was sufficient to differentiate resistant and susceptible chile plants, and was sufficient to detect differential expression in response to the pathogen using qRT-PCR. Field conditions for crop exposure to the pathogen are expected to be lower than the high levels used for gene expression studies (Richins et al., 2010), so demonstrating that gene expression changes occur at lower levels as shown here is important to establish the relevancy of these findings.

\section{Conclusion}

This study was conducted to identify gene expression changes that differentiated resistant and susceptible $C$. annuum responses to two races of $P$. capsici with different levels of virulence. Reliable and robust increases in transcription of CWP were observed only in the resistant CM334 genotype in response to inoculation with $P$. capsici. This pattern of expression occurs also in root rot (Richins et al., 2010); therefore, the gene encoding the CWP could be a candidate for a general molecular marker for resistance to $P$. capsici. Furthermore, this study clearly demonstrated that the methods developed to monitor gene expression changes using field relevant inoculation concentrations were in fact sufficient to detect changes in gene expression. Using this technique, we demonstrated that CM334 and NMH6-4 had different gene expression patterns following inoculation with $P$. capsici. This study was not able to detect race specific differential expression in any of the four genes as a function of inoculation, suggesting the genes have a basal function in plant defense. The results of this study also clearly demonstrate different expression of XEGIP encoding genes, depending on type of tissue tested, and upon cultivars.

\section{Literature Cited}

Alcantara, T. and P.W. Bosland. 1994. An inexpensive disease screening technique for foliar blight of chile pepper seedlings. HortScience 29:1182-1183.

Bnejdi, F., M. Saadoun, M. Allagui, and M. Gazah. 2009. Epistasis and heritability of resistance to Phytophthora nicotianae in pepper (Capsicum апnuum). Euphytica 167:39-44.

Burden, D. 2014. Bell and chili pepper profile. Agricultural marketing resource center. $27 \mathrm{Apr}$. 2015. <http://www.agmrc.org/>.

Castro-Rocha, A., P. Fernandez, and A. Osuna 2012. Chili defense mechansims in the Capsicum annuum-Phytophthora capsici pathosystem. Rev. Mex. Fitopatol. 30:49-65.
Choi, H.W., N.H. Kim, Y.K. Lee, and B.K. Hwang. 2013. The pepper extracellular xyloglucanspecific endo-beta-1,4-glucanase inhibitor protein gene, CaXEGIP1, is required for plant cell death and defense responses. Plant Physiol. 161:384-396.

Ghareeb, H., A. Bozso, P.G. Ott, and K. Wydra. 2011. Silicon and Ralstonia solanacearum modulate expression stability of housekeeping genes in tomato. Physiol Mol. Plant Pathol. 75:176-179.

Hayashi, T. 1989. Xyloglucans in the primary cell wall. Annu. Rev. Plant Physiol. Plant Mol. Biol. 40:139-168

Hückelhoven, R. 2007. Cell wall-associated mechanisms of disease resistance and susceptibility. Annu. Rev. Phytopathol. 45:101-127.

Jones, R.W., M. Ospina-Giraldo, and K. Deahl. 2006. Gene silencing indicates a role for potato endoglucanase inhibitor protein in germplasm resistance to late blight. Amer. J. Potato Res. $83: 41-46$

Jones, R.W. 2012. Multiple copies of genes encoding XEGIPs are harbored in an $85-\mathrm{kB}$ region of the potato genome. Plant Mol. Biol. Rpt. 30:1040-1046.

Kerk, D., J. Bulgren, D.W. Smith, and M. Gribskov. 2003. Arabidopsis proteins containing similarity to the Universal Stress Protein domain of bacteria. Plant Physiol. 131:1209-1219.

Keyhaninejad, N., J. Curry, J. Romero, and M.A. O'Connell. 2014. Fruit specific variability in capsaicinoid accumulation and transcription of structural and regulatory genes in Capsicum fruit. Plant Sci. 215-216:59-68.

Kilcrease, J., L. Rodriguez-Uribe, R.D. Richins, J.M. Garcia Arcos, J. Victorino, and M.A. O'Connell. 2015. Correlations of carotenoid content and transcript abundances for fibrillin and carotenogenic enzymes in Capsicum annum fruit pericarp. Plant Sci. 232:57-66.

Lamour, K., R. Stam, J. Jupe, and E. Huitema. 2012. The oomycete broad-host-range pathogen Phytophthora capsici. Mol. Plant Pathol. 13:329-337.

Lee, J., W.P. Lee, B.-C. Kang, and J.B. Yoon. 2012. Inheritance of resistance to Phytophthora root rot in chili pepper depending on inoculum density and parental genotypes. Kor. J. Breed. Sci. 44:503-509.

Leonian, L. 1922. Stem and fruit blight of peppers caused by Phytophthora capsici. Phytopathology 12:401-408.

Lu, Y., L. Xie, and J. Chen. 2012. A novel procedure for absolute real-time quantification of gene expression patterns. Plant Methods 8:9.

Monroy-Barbosa, A. and P.W. Bosland. 2008. Genetic analysis of Phytophthora root rot racespecific resistance in chile pepper. J. Amer. Soc. Hort. Sci. 133:825-829.

Monroy-Barbosa, A. and P.W. Bosland. 2010. A rapid technique for multiple-race disease screening of Phytophthora foliar blight on single Capsicum annuum L. plants. HortScience 45:1563-1566.

Oelke, L.M., R. Steiner, and P.W. Bosland. 2003. Differentiation of race specific resistance to Phytophthora root rot and foliar blight in Capsicum annuum. J. Amer. Soc. Hort. Sci. 128:213-218.

Rehrig, W.Z., H. Ashrafi, T. Hill, J. Prince, and A. Van Deynze. 2014. CaDMRI cosegregates with QTL Pc5.1 for resistance to Phytophthora capsici in pepper (Capsicum annuum). Plant Genome 7 doi: 10.3835/plantgenome2014.03.0011.

Richins, R.D., S. Micheletto, and M.A. O'Connell. 2010. Gene expression profiles unique to chile 
(Capsicum annuum L.) resistant to Phytophthora root rot. Plant Sci. 178:192-201.

Rodriguez-Uribe, L., I. Guzman, W. Rajapakse, R.D. Richins, and M.A. O'Connell. 2012. Carotenoid accumulation in orange-pigmented Capsicum anпuиm fruit, regulated at multiple levels. J. Expt. Bot. 63:517-526.

Scarafoni, A., A. Ronchi, and M. Duranti. 2010. $\gamma$-Conglutin, the Lupinus albus XEGIP-like protein, whose expression is elicited by chitosan, lacks the typical inhibitory activity against GH12 endo-glucanases. Phytochemistry $71: 142-148$.

Sellars, M.J., T. Vuocolo, L.A. Leeton, G.J. Coman, B.M. Degnan, and N.P. Preston. 2007. Real-time RT-PCR quantification of Juruma shrimp transcripts: A comparison of relative and absolute quantification procedures. J. Biotechnol. 129:391-399.

Sels, J., J. Mathys, B.M.A. De Coninck, B.P.A. Cammue, and M.F.C. De Bolle. 2008. Plant pathogenesis-related (PR) proteins: A focus on PR peptides. Plant Physiol. Biochem. 46:941-950.
Shin, R., G.-J. Lee, C.-J. Park, T.-Y. Kim, J.-S. You, Y.-W. Nam, and K.-H. Paek. 2001. Isolation of pepper mRNAs differentially expressed during the hypersensitive response to tobacco mosaic virus and characterization of a proteinase inhibitor gene. Plant Sci. 161:727-737.

Soh, H., A. Park, S. Park, K. Back, J. Yoon, H. Park, and Y. Kim. 2012. Comparative analysis of pathogenesis-related genes between fungal resistant and susceptible peppers. Eur. J. Plant Pathol. 132:37-48.

Sy, O., R. Steiner, and P.W. Bosland. 2005. Inheritance of Phytophthora stem blight resistance as compared to Phytophthora root rot and Phytophthora foliar blight resistance in Capsicum annuum L. J. Amer. Soc. Hort. Sci. 130:75-78.

Sy, O., R. Steiner, and P.W. Bosland. 2008. Recombinant inbred lines differential identifies race specific resistance to Phytophthora root rot in Capsicum annuum. Phytopathology 98:867-870.

Thines, M. and S. Kamoun. 2010. Oomycete-plant coevolution: Recent advances and future prospects. Curr. Opin. Plant Biol. 13:1-7.
Truong, N., E. Liew, and L. Burgess. 2010. Characterization of Phytophthora capsici isolates from black pepper in Vietnam. Fungal Biol. 114:160-170.

Tuite, J. 1967. Plant pathological methods. Fungi and bacteria: Burgess Pub., Minneapolis, MN

Van Loon, L. and E. Van Strien. 1999. The families of pathogenesis-related proteins, their activities and comparative analysis of PR-1 type proteins. Physiol. Mol. Plant Pathol. 55:85-97.

Walker, S. and P.W. Bosland. 1999. Inheritance of Phytophthora root rot and foliar blight resistance in pepper. J. Amer. Soc. Hort. Sci. 124:14-18.

Wise, R.P., M.J. Moscou, A.J. Bogdanove, and S.A. Whitham. 2007. Transcript profiling in host-pathogen interactions. Annu. Rev. Phytopathol. 45:329-369.

Yoshizawa, T., T. Shimizu, H. Hirano, M. Sato, and H. Hashimoto. 2012. Structural basis for inhibition of xyloglucan-specific endobeta-1,4-glucanase (XEG) by XEG-protein inhibitor. J. Biol. Chem. 287:18710-18716. 